\title{
Prevalence of Antibodies to Neospora caninum in White-Tailed Deer, Odocoileus virginianus, From the Southeastern United States
}

\author{
Author(s): David S. Lindsay, S. E. Little, W. R. Davidson \\ Source: Journal of Parasitology, 88(2):415-417. 2002. \\ Published By: American Society of Parasitologists \\ DOI: http://dx.doi.org/10.1645/0022-3395(2002)088[0415:POATNC]2.0.CO;2 \\ URL: http://www.bioone.org/doi/full/10.1645/0022-3395\%282002\%29088\%5B0415\%3APOATNC \\ $\% 5 \mathrm{D} 2.0 . \mathrm{CO} \% 3 \mathrm{~B} 2$
}

BioOne (www.bioone.org) is a nonprofit, online aggregation of core research in the biological, ecological, and environmental sciences. BioOne provides a sustainable online platform for over 170 journals and books published by nonprofit societies, associations, museums, institutions, and presses.

Your use of this PDF, the BioOne Web site, and all posted and associated content indicates your acceptance of BioOne's Terms of Use, available at www.bioone.org/page/terms_of_use.

Usage of BioOne content is strictly limited to personal, educational, and non-commercial use. Commercial inquiries or rights and permissions requests should be directed to the individual publisher as copyright holder. 

Vol. 88, No. 2, pp. 415-417. doi: http://dx.doi.org/10.1645/0022-3395(2002)088[0415:POATNC]2.0.CO;2

\section{Prevalence of Antibodies to Neospora caninum in White-Tailed Deer, Odocoileus virginianus, From the Southeastern United States}

David S. Lindsay, S. E. Little ${ }^{\star}$, and W. R. Davidsont, Center for Molecular Medicine and Infectious Diseases, Department of Biomedical Sciences and Pathobiology, Virginia-Maryland Regional College of Veterinary Medicine, Virginia Tech, 1410 Prices Fork Road, Blacksburg, Virginia 24061-0342; * Department of Medical Microbiology and Parasitology, College of Veterinary Medicine, University of Georgia, Athens, Georgia 30602; † Southeastern Cooperative Wildlife Disease Study, D. B. Warnell School of Forestry and College of Veterinary Medicine, University of Georgia, Athens, Georgia 30602; e-mail: lindsayd@vt.edu

ABSTRACT: Serum samples from 305 white-tailed deer (Odocoileus virginianus) from 14 states in the southeastern United States were examined for antibodies to Neospora caninum using a direct agglutination test. Positive agglutination titers were found in 145 (48\%) of the whitetailed deer examined: $21(7 \%)$ had titers of 1:25, $92(30 \%)$ had titers of $1: 50$, and $32(10 \%)$ had titers of $\geq 1: 500$. These findings that antibodies to $N$. caninum are common in white-tailed deer support the con- cept that a sylvatic cycle might exist for this economically important parasite of domestic cattle.

Neospora caninum is recognized as a cause of neonatal neuromuscular disease in dogs and abortion in cattle worldwide (reviewed by Dubey and Lindsay, 1996; Lindsay and Dubey, 2000). Dogs are a de- 
finitive host and excrete coccidial oocysts in their feces after ingesting $N$. caninum tissue cysts (McAllister et al., 1998; Lindsay, Dubey, and Duncan, 1999; Lindsay, Upton, and Dubey, 1999). However, little is known about the prevalence of the parasite in wildlife populations. Neospora caninum antibodies have been found in coyotes (Lindsay et al., 1996), dingos (Barber et al., 1997), and red foxes (Barber et al, 1997; Buxton et al., 1997; Simpson et al., 1997), suggesting a role for wild canids in the epidemiology of neosporosis. Dubey et al. (1999) found that $162(41 \%)$ of 400 white-tailed deer (Odocoileus virginianus) from northeastern Illinois had agglutinating antibodies to $N$. caninum A fatal case of neosporosis has been found in a 2-mo-old black-tailed deer fawn (O. hemionus columbianus) from California (Woods et al. 1994). These reports suggest that a wild canid-wild ruminant cycle might exist for $N$. caninum.

The present study was done to determine the prevalence of antibodies to $N$. caninum in white-tailed deer from the southeastern United States. Samples were collected from 305 white-tailed deer by members of the Southeastern Cooperative Wildlife Disease Study, College of Veterinary Medicine, University of Georgia, Athens, Georgia. Samples were sent to the Center for Molecular Medicine and Infectious Diseases, Department of Biomedical Sciences and Pathobiology, Virginia-Maryland Regional College of Veterinary Medicine, Virginia Tech, Blacksburg, Virginia, for serological testing for agglutinating antibodies to $N$. caninum.

Tachyzoites of the NC-1 strain of $N$. caninum were used as antigen for the Neospora agglutination test (NAT). The general procedure described by Packham et al. (1998) was used with slight modifications. Briefly, tachyzoites were collected from infected African green monkey (Cercopithecus aethiops) kidney cells (CV-1 cells, ATTC CCL-70, American Type Culture Collection, Manassas, Virginia) and purified from host cells by passage through a 27 -ga needle attached to a $10-\mathrm{ml}$ syringe and filtration through a $3-\mu \mathrm{m}$ filter. The purified tachyzoites were fixed in $2 \mathrm{ml}$ of $37 \%$ formaldehyde solution, which was then diluted to $6 \%$ with phosphate-buffered saline (PBS) and stored at $4 \mathrm{C}$. Prior to use in the NAT, the tachyzoites were washed twice in PBS and resuspended in alkaline buffer containing eosin (Packham et al., 1998) at $4 \times 10^{7}$ tachyzoites $/ \mathrm{ml}$ and $0.2 \mathrm{M} 2$-mercaptoethanol. The eosin aided in the visualization of the agglutination reaction, and the mercaptoethanol was added to destroy IgM antibodies and prevent nonspecific agglutination caused by IgM molecules. The direct agglutination test was conducted in 96-well, round-bottom plates. Test sera were diluted with PBS, and $25 \mu 1$ of serial test dilutions was added to $75 \mu 1$ antigen solution and mixed thoroughly by pipetting up and down several times. Positive serum from $N$. caninum-infected mice and negative control sera from mice not infected were run on each plate. Sera from mice infected with Toxoplasma gondii and Sarcocystis neurona were also used on each plate as controls. The plates were covered and incubated overnight at $37 \mathrm{C}$ in a $\mathrm{CO}_{2}$ incubator. The reaction was read the next morning. Diffuse white opacity across the entire diameter of the well was considered a positive agglutination reaction. A central discrete opaque dot or button was considered a negative reaction.

Serum samples from 145 (48\%) of the 305 white-tailed deer examined were positive (Table I). Positive white-tailed deer samples were present in all 14 states. Of the positive white-tailed deer, 21 (7\%) had titers of $1: 25,92(30 \%)$ had titers of $1: 50$, and $32(10 \%)$ had titers of $\geq 1: 500$.

The results of the present study indicate that $48 \%$ of white-tailed deer from the southeastern United Sates have antibodies to $N$. caninum, similar to the $41 \%$ of white-tailed deer from northeastern Illinois reported by Dubey et al. (1999). These studies indicate that exposure to $N$. caninum by white-tailed deer is common. Because white-tailed deer are ruminants, it is likely that they become infected by ingesting $N$. caninum oocysts while feeding or drinking. The effect of $N$. caninum on whitetailed deer populations is not known. The finding of neonatal neosporosis in a black-tailed deer (Woods et al., 1994) indicates the potential for disease in white-tailed deer as well.

Dogs are the only known definitive host for $N$. caninum (McAllister et al., 1998; Lindsay, Dubey, and Duncan, 1999; Lindsay, Upton, and Dubey, 1999). Antibodies to $N$. caninum have been found in wild canids, but patent infections or clinical disease has not been observed (Lindsay and Dubey, 2000). Domestic dogs excrete relatively few $N$. caninum oocysts in their feces (Lindsay, Dubey, and Duncan, 1999; Lindsay et al., 2001), indicating that they are a poor definitive host. The role of wild canids needs to be studied further to determine their importance in the transmission of $N$. caninum.

We thank Kay Carlson, Virginia-Maryland Regional College of Veterinary Medicine, Virginia Tech, for technical assistance. The contribution of D.S.L. was supported in part by a Clinical Research grant from Virginia-Maryland Regional College of Veterinary Medicine, Virginia Tech.

\section{LITERATURE CITED}

Barber, J. S., R. B. Gasser, J. Ellis, M. P. Reichel, D. McMillan, AND A. J. TREES. 1997. Prevalence of antibodies to Neospora caninum in different canid populations. Journal of Parasitology 83: 1056-1058.

Buxton, D., S. W. Maley, P. P. Pastoret, B. Brochier, and E. A. INNES. 1997. Examination of red foxes (Vulpes vulpes) from Belgium for antibody to Neospora caninum and Toxoplasma gondii. Veterinary Record 141: 308-309.

DubeY, J. P., AND D. S. LiNDSAY. 1996. A review of Neospora caninum and neosporosis. Veterinary Parasitology 67: 1-59.

TABLE I. Prevalence of agglutinating antibodies to Neospora caninum in white-tailed deer from the southeastern United States.

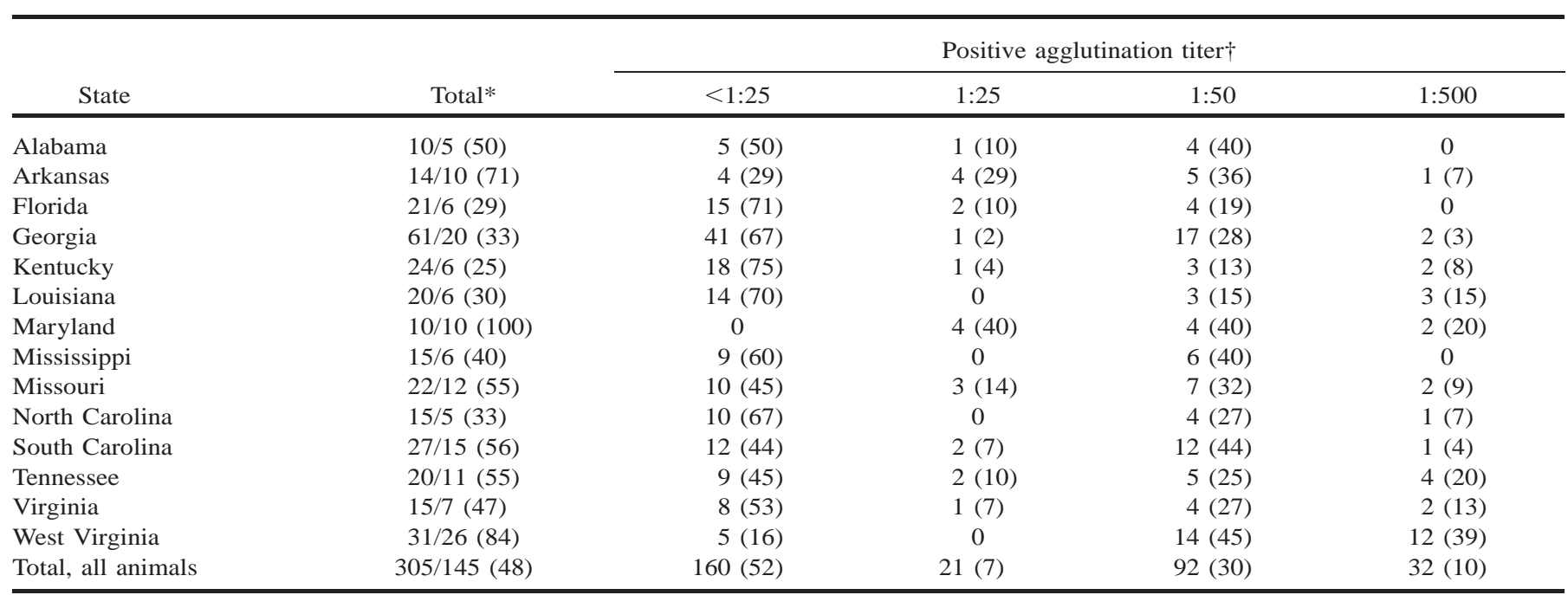

\footnotetext{
* Total number sampled/number positive (percent positive from that state)
}

$\dagger$ Number positive at that titer (percent of total for that state). 
K. Hollis, S. Romand, P. Thulliez, O. C. H. Kwok, L. HunGERFORD, C. ANCHOR, AND D. ETTER. 1999. High prevalence of antibodies to Neospora caninum in white-tailed deer (Odocoileus virginianus). International Journal for Parasitology 29: 1709-1711.

Lindsay, D. S., And J. P. Dubey. 2000. Canine neosporosis. Journal of Veterinary Parasitology 14: 1-11. , - AND R. B. DunCAN. 1999. Confirmation that the dog is a definitive host for Neospora caninum. Veterinary Parasitology 82: $327-333$.

J. E. Kelly, R. McKown, F. J. Stein, J. Herman, J. P. Dubey, AND B. L. BlagbuRN. 1996. Prevalence of Neospora caninum and Toxoplasma gondii antibodies in coyotes (Canis latrans) and experimental infections of coyotes with Neospora caninum. Journal of Parasitology 82: 657-659.

, D. M. RitTer, AND D. BRAKE. 2001. Oocyst excretion in dogs fed mouse brains containing tissue cysts of a cloned line of $\mathrm{NeO}$ spora caninum. Journal of Parasitology 87: 909-911

, S. J. UPTON, AND J. P. DUBEY. 1999. A structural study of the
Neospora caninum oocyst. International Journal for Parasitology 29: $1521-1523$.

McAllister, M. M., J. P. Dubey, D. S. Lindsay, W. R. Jolley, A. N. Wills, AND A. M. MCGuire. 1998. Dogs are definitive hosts of Neospora caninum. International Journal for Parasitology 28: 1473-1478.

Packham, A. E., K. W. Sverlow, P. A. Conrad, E. F Loomis, J. D. Rowe, M. L. Anderson, A. E. Marsh, C. Cray, and B. C. Barr. 1998. A modified agglutination test for Neospora caninum: Development, optimization, and comparison to the indirect fluorescentantibody test and enzyme-linked immunosorbent assay. Clinical Diagnostic Laboratory Immunology 5: 467-473.

Simpson, V. R., R. J. Monies, P. Riley, And D. S. Cromey. 1997. Foxes and neosporosis. Veterinary Record 141: 503.

Woods, L. W., M. L. Anderson, P. K. Swift, and K. W. Sverlow. 1994. Systemic neosporosis in a California black-tailed deer (Odocoileus hemionus columbianus). Journal of Veterinary Diagnostic Investigation 6: 508-510. 